\title{
Taxonomy of the Aerobic Pseudomonads: Pseudomonas diminuta and $P$. vesiculare
}

\author{
By R. W. BALLARD, M. DOUDOROFF AND R. Y. STANIER \\ Department of Bacteriology and Immunology, University of California, \\ Berkeley, California 94720, U.S.A. \\ AND M. MANDEL \\ Section of Molecular Biology, Department of Biology, The University of \\ Texas, M.D. Anderson Hospital and Tumor Institute, Houston, Texas, U.S.A.
}

(Accepted for publication 29 April 1968)

\begin{abstract}
SUMMARY
Thirteen strains previously assigned to the species Pseudomonas diminuta and $P$. vesiculare were subjected to detailed characterization. Ten of these strains could be identified as $P$. diminuta and two as $P$. vesiculare. These two species can be readily distinguished by differences in their nutritional spectra, their growth factor requirements and their pigmentation. The DNA of the two strains of $P$. vesiculare contained 65.8 moles $\%$ guanine + cytosine (GC), and the DNA of the ten strains of $P$. diminuta from $66 \cdot 3$ to $67 \cdot 3$ moles $\%$. One of the 13 strains examined had DNA of significantly lower GC content $(62 \cdot 2$ moles $\%$ ) and also differed in several phenotypic respects from both species; it is probably a monotypic representative of a third species, as yet unnamed.

All the strains examined share a series of distinctive properties, which justify their recognition as a special subgroup of aerobic pseudomonads. The defining characters of this subgroup include: monotrichous flagellation, with flagella of very short wavelength; a requirement for pantothenate, biotin and cyanocobalamin; a limited range of carbon sources; production of acid from primary alcohols by all strains that can utilize alcohols; inability to denitrify or to use nitrate as a nitrogen source; and accumulation of poly- $\beta$-hydroxybutyrate as an intracellular reserve.
\end{abstract}

\section{INTRODUCTION}

Pseudomonas diminuta was described by Leifson \& Hugh (1954), on the basis of the study of three closely similar strains isolated from streams. The outstanding character of the species, according to these authors, was its unusual flagellar structure. The organisms were monotrichous and the flagellum very tightly coiled. The mean wavelength was only $0.6 \mu$, whereas the flagellar wavelength of most polar monotrichous bacteria is approximately $2 \mu$. Little other information concerning the properties of this species is available. Leifson \& Hugh (1954) reported that it failed to produce acid from carbohydrates and gave negative responses to other routine biochemical tests, but formed acid from ethanol at concentrations as high as $5 \%(\mathrm{v} / \mathrm{v})$.

In the course of our taxonomic analysis of the aerobic pseudomonads (Stanier, Palleroni \& Doudoroff, 1966; Redfearn, Palleroni \& Stanier, I966) ten strains that had been tentatively identified as members of this species on the basis of their flagellar structure were received from Dr H. Lautrop of the Statens Seruminstitut in Copen- 
hagen. None of them could grow in simple defined media containing any one of a variety of organic compounds as sole carbon source; a preliminary study of their nutrition by $\mathrm{Dr}$ N. J. Palleroni suggested that the growth factor requirements were relatively complex.

We have now ascertained the minimal nutritional requirements of these bacteria, and have completed their phenotypic characterization by the methods previously applied to other aerobic pseudomonads (Stanier et al. 1966). In addition to the collection of strains received from Dr Lautrop, we have examined the type strain (ATCC I I 568) and one other strain (ATCC 13 I84) of Pseudomonas diminuta, together with the type strain (ATCC I I426) of P. vesiculare. The latter organism was originally described as a Corynebacterium (Busing, Doll \& Freytag, 1953), but was shown by Galarneault \& Leifson (1964) to be a Pseudomonas sp., and Dr R. Hugh suggested to us (personal communication) that it might resemble $P$. diminuta. This inference has been confirmed: $P$. diminuta and $P$. vesiculare are closely similar species. They share a series of properties unusual among the aerobic pseudomonads so far examined.

\section{METHODS}

\section{Origins of the strains examined}

We shall refer to the strains by the numbers assigned to them in the collection of pseudomonads maintained in the Department of Bacteriology and Immunology of the University of California, Berkeley. Named strains of Pseudomonas diminuta (50I, 502) and $P$. vesiculare (500) were obtained from the American Type Culture Collection; the others (ten in all) were provided by Dr H. Lautrop, Statens Seruminstitut, Copenhagen, Denmark; their origins are indicated below. All these strains had been tentatively identified as $P$. diminuta by Dr Lautrop on morphological grounds.

500. P. vesiculare (Busing et al. 1953) Galarneault \& Leifson (I964) (type strain). Corynebacterium vesiculare ATCC 1 1426. Isolated from the urinary-bladder epithelium of the leech Hirudo medicinalis.

50I. P. diminuta Leifson \& Hugh (I954; type strain). ATCC I I568. Isolated from a stream.

502. $P$. diminuta ATCC $\mathrm{I} 3 \mathrm{I} 84$. Isolated from buccal cavity.

230. Lautrop AB I02. Isolated from whooping-cough plate. 23I. Lautrop AB 236. Isolated from spinal fluid. 232. Lautrop AB 265. Isolated from throat swab. 233. Lautrop AB 328. Culture received for identification. 234. Lautrop AB 359. Culture received for identification. 235. Lautrop AB I122. Isolated from ear swab. 236. Lautrop AB 1224. Isolated from ascitic fluid. 237. Lautrop AB 1267. Isolated from urine. 238. Lautrop AB 1268 . Isolated from pus from maxillary sinus. 239. Lautrop AB 1278 . Isolated from blood culture.

\section{Media}

All media used in these studies were prepared with the standard mineral base described by Stanier et al. (1966). Yeast extract was prepared by adding Difco yeast extract $5 \mathrm{~g}$./1. to the standard mineral base, and yeast agar by the further addition of Difco agar $20 \mathrm{~g} . / 1$. These complex media were used for routine cultivation and maintenance of stocks. 
Except in studies on specific growth factor requirements, chemically defined media were prepared by adding an appropriate organic carbon and energy source to the standard mineral base, together with a supplement of 15 vitamins $(0.4 \mathrm{mg}$./1. each of: $p$-aminobenzoic acid, folic acid, biotin, nicotinic acid, nicotinamide, Ca pantothenate, riboflavin, thiamine, pyridoxal, pyridoxine, 2-methyl-I,4-naphthoquinone, choline, lipoic acid, haem, cyanocobalamin). Defined media for all strains except 230 and 500 were also supplemented with cystine $50 \mathrm{mg} . / 1$.

All cultures were incubated at $30^{\circ}$ unless otherwise stated.

\section{Nutritional requirements and gross physiology}

The minimal growth factor requirements of all strains were determined by successive omissions of various amino acids or vitamins from a chemically defined medium containing the standard mineral base, 19 amino acids (L-cysteine, $50 \mathrm{mg} . / 1$. DL-threonine, $20 \mathrm{mg}$./l. and Io mg./l. each of DL-lysine hydrochloride, DL-arginine, L-methionine, L-leucine, L-isoleucine, DL-valine, DL-phenylalanine, L-tyrosine, DL-tryptophan, L-histidine monohydrochloride, DL-glutamate- $\mathrm{H}_{2} \mathrm{O}$, L-proline, DL-aspartate, DL-alanine, glycine, DL-serine, and hydroxy-L-proline) and the 15 vitamins listed above. Sodium acetate $(0.1 \%$, w/v, of the anion) was used as the principal carbon and energy source. After the minimal requirements for each strain had been ascertained, the suitability of the minimal medium was confirmed by making six successive serial transfers, using $0.0 \mathrm{I} \mathrm{ml}$. of inoculum per $5 \mathrm{ml}$. of medium.

One hundred and forty-six different carbon compounds were tested as carbon + energy sources by the replica plating method described by Stainer et al. (1966). Cystine and I5 vitamins (listed above) were added to the plates, before pouring, to give a final concentration in the agar media of about cystine $50 \mathrm{mg}$. $/ 1$. and $0.4 \mathrm{mg}$. $/ 1$. of each of the I5 vitamins. In all cases where growth on plates was questionable, utilization of the carbon sources in question was tested in chemically defined liquid media.

The ability to utilize nitrate as sole nitrogen source was determined by using the liquid standard mineral base medium, in which the $\left(\mathrm{NH}_{4}\right)_{2} \mathrm{SO}_{4}$ was replaced by $\mathrm{KNO}_{3}(3 \mathrm{~g}$./1.), and acetate (I g./1.) was supplied as the carbon + energy source. Four successive transfers of each culture were made in the same medium, using an inoculum of $0.02 \mathrm{ml}$. into $5 \mathrm{ml}$. at each transfer.

Nitrate reduction was tested in yeast extract medium with the $\left(\mathrm{NH}_{4}\right)_{2} \mathrm{SO}_{4}$ replaced by $\mathrm{KNO}_{3}(3 \mathrm{~g} . / \mathrm{l}$.) and in the standard defined medium containing acetate as carbon source and $\mathrm{KNO}_{3}$ (g./l.) either in addition to or in place of the $\left(\mathrm{NH}_{4}\right)_{2} \mathrm{SO}_{4}$. Cultures in ro $\mathrm{ml}$. of these media were incubated without shaking and subsequently examined for the production of nitrite by Trommsdorff's test (Feigl, 1954) and of ammonia by Nessler's reaction (Hawk, Oser \& Summerson, 1947).

Denitrification was tested by the methods of Stanier et al. (1966) in yeast extract medium and in the standard mineral medium, with acetate (I g./l.) carbon + energy source.

\section{Endogenous reserve materials}

Presumptive evidence for the accumulation of poly- $\beta$-hydroxybutyrate (PHB) as an intracellular reserve material was obtained by microscopic examination, as described by Stanier et al. (1966). Presence of the PHB was confirmed by isolating the granules 
from hypochlorite-treated bacteria and subjecting them to the action of the $\mathrm{PHB}$ depolymerase of Pseudomonas lemoignei, as described by Delafield et al. (1965).

Quantitative tests for the accumulation of PHB and of glucose polysaccharide were done by growing the organisms in the defined mineral medium containing $0.15 \%$ of either glucose or DL- $\beta$-hydroxybutyrate as carbon source. The bacteria were harvested and resuspended in $0.04 \mathrm{M}$-phosphate buffer ( $\mathrm{pH} \mathrm{6.8).} \mathrm{Samples} \mathrm{of} \mathrm{the} \mathrm{suspension} \mathrm{were}$ incubated with shaking at $30^{\circ}$ in the presence or absence of carbon and nitrogen sources. After $6 \mathrm{hr}$, the bacteria were harvested by centrifugation and the dry weights determined. The PHB content of the bacteria was estimated by the method of Slepecky \& Law (1960). Glucose polysaccharide content was measured by the use of the glucose oxidase-peroxidase reagent ('Glucostat', Worthington Biochemical Corp., Freehold,

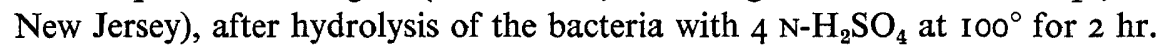

\section{Extraction and characterization of the orange pigments of strains 230 and 500}

To determine the nature of the orange pigment(s) of strains 230 and 500, the bacteria were grown in yeast-extract medium with constant shaking for $48 \mathrm{hr}$ and then harvested by centrifugation. The pigment was extracted from the bacteria by three successive treatments with $\mathrm{ro} \mathrm{ml}$. absolute methanol/g. wet bacteria. Each extraction was done for $5 \mathrm{~min}$. at room temperature and the bacteria removed by centrifugation. The final pellet of bacteria was colourless.

After addition of methanolic $\mathrm{KOH}$ to final concentration $3 \% \mathrm{KOH}$, the methanolic extract was saponified for Io min. at $50^{\circ}$. One-tenth volume of water was then added, and the extract acidified with concentrated $\mathrm{HCl}$. Upon acidification, the colour of the extract changed from orange-yellow to orange-red. After the further addition of an equal volume of water, the pigments were repeatedly extracted with light petroleum (boiling range $30^{\circ}$ to $60^{\circ}$, purified by passage through a silica gel column and dehydrated with anhydrous $\mathrm{Na}_{2} \mathrm{SO}_{4}$ ). The orange-red light petroleum extract was washed several times with distilled water to remove all traces of methanol. Columns of neutral alumina, diatomaceous earth, sucrose and anhydrous $\mathrm{Na}_{2} \mathrm{SO}_{4}$ were used in an attempt to separate these pigments. The columns were eluted with light petroleum containing increasing amounts of acetone. The pigments were treated with the Carr-Price reagent (Carr \& Price, I926) to establish their carotenoid nature.

\section{Determination of the base composition of DNA}

The mole \% GC in the DNA of all strains was determined from buoyant density measurements in $\mathrm{CsCl}$ gradients (Mandel, 1966).

\section{Miscellaneous tests}

Morphological examinations were made on material from $24 \mathrm{hr}$ yeast-extract agar slopes. Flagella were stained by the method of Leifson (I95I).

The ability of strains to grow in yeast-extract medium at $4^{\circ}$ and $41^{\circ}$, to hydrolyse gelatin, Tween 80 , starch, and exogenously supplied poly- $\beta$-hydroxybutyrate, and to produce the 'egg yolk reaction' was determined as described by Stanier et al. (1966). All strains were tested for the ability to produce acid oxidatively from ethanol, $n$-propanol and various sugars, using the basal medium of Hugh \& Leifson (1953) containing I \% of each substrate. 
The oxidase test was done with bacteria from $24 \mathrm{hr}$ cultures grown on yeast-extract agar slopes, by the method described by Stanier et al. (1966).

The reduced/oxidized difference spectra of frozen preparations were determined with the Cary (model I4) recording spectrophotometer, equipped with a sensitive slide wire (total extinction span: 0.2 units) and an accessory device for maintaining sample cuvettes at the temperature of liquid nitrogen. The bacteria were harvested from cultures grown for $24 \mathrm{hr}$. in yeast-extract medium, washed, and resuspended in 0.03 M-phosphate buffer ( $\mathrm{pH} 6.8$ ) to a concentration of $20 \%$ (wet weight/volume). To establish a 'base line' for the instrument with the sample cuvette, two samples of the suspension were placed in plastic cuvettes, gassed with $\mathrm{O}_{2}$ for $10 \mathrm{~min}$. and then frozen in liquid nitrogen. The extinctions were compared over the range 390 to $650 \mathrm{~m} \mu$. The same cuvettes were then emptied and refilled with fresh suspensions. The reference cuvette was gassed with $\mathrm{O}_{2}$ while the sample was allowed to become reduced either by endogenous metabolism or by the addition of dithionate. Both cuvettes were frozen in liquid nitrogen and their spectra compared (Sands, Gleason \& Hildebrand, 1967).

\section{RESULTS}

\section{Morphology}

All the strains were Gram-negative rods (about $0.5 \times$ I to $4 \mu$ ) with predominantly polar monotrichous flagella of short wavelength $(0.6$ to $\mathrm{I} \cdot 0 \mu)$, as previously demonstrated by Leifson \& Hugh (1954), Galarneault \& Leifson (1964) and Dr H. Lautrop (personal communication).

\section{Growth factor requirements}

All I 3 strains could grow in a chemically defined medium containing acetate $(0 \cdot I \%$, $\mathrm{w} / \mathrm{v}$, of the anion) as the principal carbon + energy source, supplemented with 19 amino acids and 15 vitamins. The minimum growth requirements (Table I) were determined by successive omissions of amino acids and vitamins from this medium. Every strain required three vitamins: pantothenate, biotin, cyanocobalamin. These supplements were sufficient to support growth of the type strain of Pseudomonas vesiculare (500) and of one other strain (230). The remaining I I strains also required cystine, replaceable (although less effectively) by methionine. Three other sulphur compounds tested (thiosulphate, thioglycollate. DL-homocysteine) were unable to replace cystine.

Table I. Organic growth factor requirements of Pseudomonas strains examined

$\begin{array}{lcccc}\text { Strain } & \begin{array}{c}\text { Panto- } \\ \text { thenate }\end{array} & \text { Biotin } & \begin{array}{c}\text { Cyano- } \\ \text { cobalamin }\end{array} & \text { Cystine } \\ \text { 230, 500 } & + & + & + & - \\ \text { 23I-239, 501, 502 } & + & + & + & +*\end{array}$

* Can be replaced by methionine, but growth is considerably slower; not replaceable by thiosulphate, thioglycollate or DL-homocysteine.

\section{Utilization of carbon and energy sources}

The diminuta group can use relatively few carbon compounds as principal carbon + energy sources: only 8 of the 146 compounds examined could be used by all strains (Table 2). Universal substrates include four amino acids ( $L$ - and $D$ - $\alpha$-alanine, L-gluta- 
mate, L-proline) and four organic acids (acetate, pyruvate, butyrate, DL- $\beta$-hydroxybutyrate). Nineteen other compounds could be used by some, but not all, strains (Table 3). With respect to the utilization of these additional compounds, the type strain of Pseudomonas vesiculare (500) and strain 230 can be clearly distinguished from the remaining strains by virtue of their ability to use certain carbohydrates (D-glucose, D-galactose, maltose, cellobiose) and their failure to use L-histidine or pantothenate as carbon sources.

In view of the report by Leifson \& Hugh (1954) that acid was produced from ethanol by Pseudomonas diminuta, this property was re-examined. With the exception of

Table 2. Utilization of carbon compounds as substrates by the diminuta group

Class of compounds

Hydrocarbons

Fatty acids

Dicarboxylic acids

Hydroxyacids

Miscellaneous organic acids

Alcohols, glycols, polyalcohols

Carbohydrates and sugar acids

Non-nitrogenous aromatic and other cyclic compounds

Amines

Aliphatic amino acids

Amino acids and related L-proline compounds containing a ring structure

Miscellaneous nitrogenous compounds

Pyruvate
Compounds utilized by all strains

Compounds not utilized by any strains $n$-dodecane, $n$-hexadecane

Acetate, butyrate Isobutyrate, valerate, isovalerate, caproate, heptanoate, caprylate, pelargonate, caprate

Oxalate, malonate, maleate, glutarate, adipate, pimelate, suberate, azelate, sebacate, eicosanedioate

DL- $\beta$-hydroxybutyrate D-Malate, D- $(-)$-tartrate, $\mathrm{L}-(+)$ tartrate, meso-tartrate, DL-lactate, glycollate, DLglycerate, poly $-\beta$-hydroxybutyrate

Citrate, laevulinate, citraconate, itaconate, mesaconate

Methanol, isopropanol, $n$-butanol, isobutanol, geraniol, ethyleneglycol, propyleneglycol, 2,3-butyleneglycol, erythritol, mannitol, sorbitol, meso-inositol, adonitol, glycerol

D-Ribose, D-xylose, D-arabinose, L-arabinose, D-fucose, L-rhamnose, D-mannose, D-fructose, sucrose, trehalose, lactose, starch, inulin, gluconate, 2-ketogluconate, saccharate, mucate, salicin

D-Mandelate, L-mandelate, benzylformate, benzoate, $o$-hydroxybenzoate, $m$-hydroxybenzoate, $p$-hydroxybenzoate, phthalate, iso-phthalate, terephthalate, phenylacetate, phenylethanediol, naphthalene, phenol, quinate, testosterone

Methylamine, ethanolamine, benzylamine, putrescine, spermine, histamine, tryptamine, butylamine, $\alpha$-amylamine

$\mathrm{L}-\alpha$-alanine, $\mathrm{D}-\alpha-\quad \quad$ Glycine, $\beta$-alanine, $\mathrm{L}$-threonine, DL-noralanine, L-glutamate leucine, L-valine, L-lysine, DL-arginine, DL-ornithine, DL-citrulline, DL- $\alpha$-aminobutyrate, $\gamma$-aminobutyrate, DL- $\alpha$-aminovalerate, $\delta$-aminovalerate

L-Tyrosine, L-phenylalanine, L-tryptophan, D-tryptophan, L-kynurenine, kynurenate, anthranilate, $m$-aminobenzoate, $p$-aminobenzoate

Betaine, sarcosine, creatine, hippurate, acetamide, nicotinate, trigonelline 
strains 502 and 235, all strains examined used both ethanol and $n$-propanol as carbon sources; these I I strains likewise produced acid in complex media supplemented with $\mathrm{I} \%(\mathrm{w} / \mathrm{v})$ of either alcohol. Growth in such media ceased when the $\mathrm{pH}$ decreased to 4.7 (about $0.05 \mathrm{M}$-acid). In defined media containing ethanol as sole carbon source, strains 230 and 500 grew and produced acid with initial ethanol concentrations up to $5 \%(\mathrm{v} / \mathrm{v})$; with low initial concentrations, the acid formed subsequently disappeared. The other nine ethanol-oxidizing strains did not grow well in defined media with ethanol concentrations greater than $0.2 \%$, and produced little if any acid under these conditions.

Table 3. Principal carbon sources utilized by some but not all of the strains of the diminuta group of Pseudomonas

\begin{tabular}{|c|c|c|c|c|c|c|c|c|}
\hline & \multicolumn{5}{|c|}{ Pseudomonas diminuta } & \multicolumn{2}{|c|}{ P. vesiculare } & \multirow{5}{*}{$\begin{array}{r}\text { Strai } \\
235\end{array}$} \\
\hline & & & 231 & & & & & \\
\hline & & 236 & 232 & & & & & \\
\hline & & 238 & 233 & & & & & \\
\hline & 502 & 239 & 501 & 237 & 234 & 500 & 230 & \\
\hline D-Glucose & - & - & - & - & - & + & + & - \\
\hline D-Galactose & - & - & - & - & - & + & + & - \\
\hline Maltose & - & - & - & - & - & + & + & - \\
\hline Cellobiose & - & - & - & - & - & + & + & - \\
\hline Propionate & - & - & - & + & - & - & - & + \\
\hline Succinate & - & - & - & - & + & + & + & - \\
\hline Fumarate & - & - & - & - & + & + & - & + \\
\hline L-Malate & - & - & - & - & + & + & + & - \\
\hline Hydroxymethylglutarate & - & - & + & - & - & - & - & - \\
\hline$\alpha$-Ketoglutarate & - & - & - & - & - & + & + & + \\
\hline Aconitate & - & - & - & - & - & - & + & - \\
\hline Ethanol & - & + & + & + & + & + & + & - \\
\hline$n$-Propanol & - & + & + & + & + & + & + & - \\
\hline L-Serine & - & - & - & - & + & - & - & - \\
\hline L-Leucine & - & - & - & - & + & - & - & + \\
\hline L-Isoleucine & - & - & - & - & + & - & - & + \\
\hline L-Aspartate & + & + & + & + & + & + & + & - \\
\hline L-Histidine & + & + & + & + & + & - & - & + \\
\hline Pantothenate & + & + & + & + & + & - & - & - \\
\hline
\end{tabular}

All strains that oxidized primary alcohols also accumulated acetone in complex media containing I \% (v/v) isopropanol, but did not grow with either isopropanol or acetone as sole carbon source. Strains 502 and 235 did not produce acetone. None of the strains produced dihydroxyacetone from glycerol or fructose from either sorbitol or mannitol in complex media supplemented with these polyols.

Only strains 230 and 500 produced acid in complex media containing carbohydrates: acid was formed by these strains from glucose, galactose, L-arabinose, D-xylose. The last two sugars did not serve as carbon sources for the organisms. The metabolism of glucose and galactose has been shown to proceed through pathways previously established in Pseudomonas saccharophila (Entner \& Doudoroff, 1952; MacGee \& Doudoroff, 1954; DeLey \& Doudoroff, I957), except that either NAD or NADP can serve as hydrogen acceptor for the initial dehydrogenation of galactose. It has been found that accumulation of 2-keto-3-deoxyaldonic acids accounts for at least part of the acid produced from these sugars, as well as from pentoses, in complex media (unpublished results). 


\section{R. W. BALLARD, M. DOUDOROFF, R. Y. STANIER AND M. MANDEL}

None of the strains grew chemolithotrophically in a mineral medium supplemented with growth factors and provided with $\mathrm{CO}_{2}$ as principal carbon source and either molecular hydrogen or thiosulphate as possible electron donor.

\section{Temperature ranges and growth rates}

Three strains $(235,237,502)$ grew in a yeast-extract medium at $41^{\circ}$. The remaining strains, which grew slightly or not at all at this temperature, grew at $37^{\circ}$. No strains produced visible turbidity after ro days at $4^{\circ}$ in yeast extract medium. More detailed experiments with the type strains of Pseudomonas diminuta (50I) and $P$. vesiculare (500) showed that growth in yeast extract medium was slightly faster at $30^{\circ}$ than at $37^{\circ}$. Quantitative determinations of growth rates for the two type strains at $30^{\circ}$ showed that their growth was relatively slow, even in complex media. The generation times (determined turbidimetrically) and maximal yields of bacteria (by dry weight measurements) with several selected substrates in defined media and in a yeast extract medium are shown in Table 4. It will be noted that no defined medium supported the growth of either type strain at a rate comparable to the rate obtained with yeast extract. This may be because the yeast extract contains growth factors, other than the essential ones, that accelerate growth. The best single carbon sources were sugars for $P$. vesiculare (500) and the two stereoisomers of alanine for P. diminuta (50I).

Table 4. Generation times and bacterial yields in yeast extract and in defined media with different substrates at $30^{\circ *}$

\begin{tabular}{|c|c|c|c|c|}
\hline & P.ves & 500 & P. $d i$ & $50 r$ \\
\hline & Generation & & Generation & \\
\hline Substrate $\uparrow$ & Time (hr) & Yield $\ddagger$ & Time (hr) & Yield $f$ \\
\hline Yeast extract (I g./l.) & $3 \cdot 2$ & . & $3 \cdot 1$ & . \\
\hline Yeast extract ( 5 g. $/ 1)$. & $2 \cdot 3$ & . & $I \cdot 3$ & . \\
\hline Glucose & $7 \cdot 4$ & 985 & . & . \\
\hline Galactose & $16 \cdot 5$ & 990 & . & . \\
\hline Ethanol & 26 & 900 & 22 & 975 \\
\hline Acetate & 12 & 800 & Io & 750 \\
\hline Butyrate & $2 I$ & 790 & 19 & 760 \\
\hline DL- $\beta$-hydroxybutyrate & $13 \cdot 5$ & 780 & 15 & 800 \\
\hline Succinate & 29 & 790 & . & . \\
\hline L-malate & 22 & 745 & . & . \\
\hline L- $\alpha$-alanine & 14 & 890 & $8 \cdot 3$ & 840 \\
\hline D- $\alpha$-alanine & 15.5 & 870 & $6 \cdot 0$ & 850 \\
\hline Proline & II & 875 & 17 & 865 \\
\hline
\end{tabular}

* Generation times and bacterial yields remained constant through three successive transfers of each culture in the same medium.

$\dagger$ Except for yeast extract, which was provided at I and 5 g./l., the initial concentration of all carbon sources in defined media was $I \mathrm{~g}$./1. (in the case of salts of organic acids, the concentration of the anion was $\mathrm{I}$ g./1.).

$\ddagger$ Micrograms dry weight of cells per mg. of substrate carbon. Yields were not determined in complex media.

\section{Endogenous reserve materials}

Under the conditions described by Stanier et al. (I966), granules of poly- $\beta$-hydroxybutyrate (PHB) were observed in all the strains tested. Identity of the PHB was established in Pseudomonas diminuta (50I), P. vesiculare (500) and strains 232 and 235 as described in Methods. During exponential growth in $\beta$-hydroxybutyrate medium, the 
bacteria of strains 232 and 50 I ( $P$. diminuta) had a relatively high PHB content (about $10 \%$ ) and a very low content of glucose polysaccharide (about $2 \%$ ) on a dry-weight basis. In contrast, exponentially growing bacteria of strain $500(P$. vesiculare) contained essentially no PHB, but considerable amounts of polysaccharide (about $10 \%$ of dry weight in $\beta$-hydroxybutyrate medium and nearly $20 \%$ in glucose medium).

The carbohydrate and PHB contents of bacterial suspensions of strains 500 and 232 incubated in the presence and absence of suitable carbon sources as described in Methods are shown in Table 5. It can be seen that the carbohydrate content of strain 232 was essentially the same in the presence and absence of $\beta$-hydroxybutyrate, while the amount of PHB was greater in the bacteria oxidizing $\beta$-hydroxybutyrate. In the case of Pseudomonas vesiculare (500), both PHB and carbohydrate contents of the bacteria were greater in the presence of $\beta$-hydroxybutyrate or glucose as exogenous substrate. The presence of a nitrogen source stimulated the breakdown of the endogenous polysaccharide.

Table 5. The intracellular accumulation of reserve materials*

\begin{tabular}{|c|c|c|c|c|c|}
\hline \multirow{3}{*}{$\begin{array}{l}\text { Organism and } \\
\text { growth substrate }\end{array}$} & \multirow{3}{*}{$\begin{array}{l}\text { Conditions of } \\
\text { incubation }\end{array}$} & \multirow{2}{*}{\multicolumn{2}{|c|}{$\begin{array}{l}\text { Bacterial weight } \\
(\mu \mathrm{g} . / \mathrm{ml} .)\end{array}$}} & \multicolumn{2}{|c|}{$\begin{array}{l}\text { Final content of re- } \\
\text { serve materials } \\
(\mu \mathrm{g} . / \mathrm{ml} .)\end{array}$} \\
\hline & & & & \multirow{2}{*}{$\begin{array}{l}\text { Glucose } \\
\text { poly- } \\
\text { saccharide }\end{array}$} & \multirow[b]{2}{*}{ PHB } \\
\hline & & Initial & Final & & \\
\hline Strain 232 & $\begin{array}{l}\text { No carbon or nitrogen } \\
\text { source }\end{array}$ & 455 & 452 & 12 & $4 \mathrm{I}$ \\
\hline $\begin{array}{l}\text { I.5 mg. DL- } \beta \text { - } \\
\text { hydroxybutyrate/ } \\
\text { ml. }\end{array}$ & $\begin{array}{l}\text { With I.5 mg. DL- } \beta- \\
\text { hydroxybutyrate } / \mathrm{ml} \text {; } \\
\text { no nitrogen source }\end{array}$ & 455 & 468 & 13 & 56 \\
\hline Strain 500 & $\begin{array}{l}\text { No carbon or nitrogen } \\
\text { source }\end{array}$ & $\begin{array}{c}\text { Not } \\
\text { determined }\end{array}$ & 1050 & 100 & $\circ$ \\
\hline $\begin{array}{l}\mathrm{I} \cdot 5 \mathrm{mg} . \mathrm{DL}-\beta \text { - } \\
\text { hydroxybutyrate/ } \\
\text { ml. }\end{array}$ & $\begin{array}{l}\text { With I. } 5 \mathrm{mg} \text {. DL- } \beta \text { - } \\
\text { hydroxybutyrate } / \mathrm{ml} \text {; } \\
\text { no nitrogen source }\end{array}$ & $\begin{array}{c}\text { Same as } \\
\text { above } \dagger\end{array}$ & I 255 & 144 & 156 \\
\hline Strain 500 & $\begin{array}{l}\text { No carbon or nitrogen } \\
\text { source }\end{array}$ & 548 & 544 & 106 & o \\
\hline \multirow[t]{2}{*}{ I.5 mg. glucose $/ \mathrm{ml}$. } & $\begin{array}{l}\text { No carbon source; } \\
\text { I } \mathrm{mg} .\left(\mathrm{NH}_{4}\right)_{2} \mathrm{SO}_{4} / \mathrm{ml} \text {. }\end{array}$ & 548 & 517 & 74 & 0 \\
\hline & $\begin{array}{l}\text { With } 1.5 \mathrm{mg} \text {. glucose/ } \\
\text { ml.; no nitrogen source }\end{array}$ & 548 & 628 & I3I & 54 \\
\hline
\end{tabular}

\section{Other physiological properties}

All the strains are obligate aerobes, and incapable of denitrification in either complex or chemically defined media. Only one strain (502) reduced nitrate to nitrite; it produced nitrite in all three of the media (defined and complex) tested.

None of the strains hydrolysed starch, gelatin, Tween 80 , or exogenously supplied poly- $\beta$-hydroxybutyrate in $48 \mathrm{hr}$; none produced the 'egg yolk reaction'. 


\section{Oxidase reaction and reduced/oxidized difference spectra}

With the exception of 230,235 and 500, all strains gave a strong positive oxidase reaction with $N, N^{\prime}$-dimethyl-p-phenylenediamine; these three exceptional strains gave a much weaker but still perceptible reaction. The reduced/oxidized difference spectra of four strains, two of which gave a strong oxidase reaction $(232,501)$ and two of which gave a weak reaction $(235,500)$, were determined and found to be qualitatively similar. All showed a peak at $628 \mathrm{~m} \mu$ corresponding to a cytochrome $a_{2}$ component, another at $598 \mathrm{~m} \mu$ corresponding to cytochrome $a_{1}$, and a peak at $557 \mathrm{~m} \mu$ and shoulder at $562 \mathrm{~m} \mu$ characteristic of a $b$-type cytochrome. All strains also showed the presence of a $c$-type cytochrome with a peak at 55I $\mathrm{m} \mu$, except for strain 235 in which the absorption maximum was displaced to $549 \mathrm{~m} \mu$.

Significant quantitative differences were observed, however, between strains that gave a strong oxidase reaction and those that gave a weak one. In the former, the amount of cytochrome $c$ was much greater than in the latter, while the amounts of cytochromes $a$ and $b$ were approximately the same in both groups. The height of the $c$ peak relative to that of the $b$ peak was 0.92 and $\mathrm{I} \cdot 0$, respectively, in strains 232 and $50 \mathrm{I}$, but only 0.66 and 0.62 , respectively, in strains 235 and 500. These results lend further support to the conclusion that the oxidase test is essentially a test for the presence or absence of a $c$-type cytochrome in the terminal respiratory chain (Baumann, Doudoroff \& Stanier, 1968; Stanier et al. I966; Sands et al. 1967).

\section{Characterization of the pigments of strains 230 and 500}

Attempts to separate the orange-red pigments extracted from strains 230 and 500 by chromatography on neutral alumina, diatomaceous earth or sucrose were unsuccessful. A degree of separation was, however, achieved by adsorption on a column of anhydrous $\mathrm{Na}_{2} \mathrm{SO}_{4}$ and elution with light petroleum containing increasing amounts of acetone; a yellow band was eluted from the column with $2.5 \%$ acetone and an orange band with $10 \%$ acetone. The absorption spectrum of the yellow pigment in pure light petroleum showed two major peaks, at 426 and $452 \mathrm{~m} \mu$, and shoulders at 403 and $477 \mathrm{~m} \mu$. The orange pigment had an absorption maximum at $488 \mathrm{~m} \mu$, a peak at $515 \mathrm{~m} \mu$ with a shoulder at $553 \mathrm{~m} \mu$, and a minor peak at $397 \mathrm{~m} \mu$.

The pigments gave a blue colour with the Carr-Price reagent, and thus appear to be carotenoids.

Table 6. DNA Composition (moles \% GC) of the strains of the diminuta group of Pseudomonas

\begin{tabular}{cl} 
Moles $\%$ GC* $^{*}$ & \multicolumn{1}{c}{ Strains } \\
$62 \cdot 2$ & 235 \\
$65 \cdot 8$ & 230,500 \\
$66 \cdot 3$ & 231,502 \\
$66 \cdot 9$ & $233,234,237,238$ \\
$67 \cdot 3$ & $232,236,239,501$
\end{tabular}

* Raw mean of two determinations. 


\section{Base composition of DNA}

The base compositions of the DNA's in all strains examined fell in the range previously shown (Mandel, I966) to be characteristic of aerobic pseudomonads (Table 6). The value for strain $235(62 \cdot 2$ moles $\%$ GC) is significantly lower than those for the remaining $\mathrm{I} 2$ strains, which are all in the narrow range $65 \cdot 8$ to $67 \cdot 3$.

\section{DISCUSSION}

The I 3 strains examined possess a considerable number of morphological, nutritional and physiological characters in common. These shared characters appear to justify their recognition as a special subgroup within the genus Pseudomonas, as defined by Stanier et al. (1966). We shall term it the 'diminuta group'. Some of the characteristic properties of the diminuta group are: (I) possession of polar monotrichous flagella of short wavelength; (2) requirement for pantothenate, biotin and cyanocobalamin; (3) inability to use nitrate as a sole nitrogen source, to perform denitrification or, with one exception (strain 502), to reduce nitrate to nitrite: (4) positive oxidase reaction of variable intensity (5) possession of $a_{1}, a_{2} ; b$, and $c$ cytochrome components; (6) accumulation of poly- $\beta$-hydroxybutyrate as an endogenous reserve material; (7) a very limited nutritional spectrum, as compared with most other pseudomonads; and (8) inability to hydrolyse starch, gelatin, Tween 80 , exogenously supplied poly- $\beta$ hydroxybutyrate, or to produce the 'egg yolk reaction'.

It should be noted that most of these strains had been provisionally grouped together on the basis of the first-mentioned character by Dr H. Lautrop, and that Dr R. Hugh had suggested a possible relationship between Pseudomonas vesiculare and $P$. diminuta on the same grounds (personal communication). However, the short wavelength of the flagella is not alone sufficient to characterize this group. A study of the hydrogenomonads (Davis, 1967) revealed the existence of other strains which have a flagellar structure like that of the diminuta group, but which do not share the distinctive physiological properties of this group.

On phenotypic grounds, eight of the ten strains tentatively identified as Pseudomonas diminuta by Dr H. Lautrop and strain 502, so identified by Dr Hugh, can be grouped with the type strain (50I) of $P$. diminuta. One of Lautrop's strains (230) is almost identical with the type strain (500) of $P$. vesiculare. Lautrop's strain 235 is the only one that cannot be readily included in either species.

Several features distinguish Pseudomonas diminuta from $P$. vesiculare (Table 7 ). The major differences are the requirement for cystine by all strains of $P$. diminuta, and utilization of sugars and the production of carotenoid pigments by $P$. vesiculare.

Although the ten strains that we have assigned to Pseudomonas diminuta show minor phenotypic differences (Table 3), we do not consider that these differences justify a taxonomic subdivision. The most aberrant strains are 502 and 234. Strain 502 does not oxidize alcohols, and is the only strain in the entire collection that produces nitrite from nitrate. Strain 234 uses six carbon sources that are not used by the other nine strains. The inability of strain 502 to use alcohols may reflect the absence of only one enzyme possessed by the other strains. Three of the carbon sources utilized uniquely by strain 234 are the closely related compounds succinate, fumarate and L-malate; this nutritional feature probably reflects possession of a single permease. 
360 R. W. BALLARD, M. DOUDOROFF, R. Y. STANIER AND M. MANDEL

Strain 235 resembles Pseudomonas diminuta in its growth-factor requirements, its ability to use L-histidine and its inability to use sugars or to produce carotenoid pigments. It resembles $P$. vesiculare in its weak oxidase reaction, ability to use $\alpha$-ketoglutarate and inability to use pantothenate as sole carbon source. Strain 235 also differs from all other strains studied (with the exception of $P$. diminuta strain 502) in its inability to oxidize alcohols. The GC content of the DNA of strain 235 is markedly lower than that of the remaining strains. These differences are summarized in Table 7. It seems probable, accordingly, that strain 235 is a monotypic representative of a third species of the group; for the time being, we prefer to leave it unnamed.

Table 7. Characters distinguishing Pseudomonas vesiculare, $P$. diminuta, and strain 235

$\begin{array}{lccc}\quad \text { Characters } & P . \text { vesiculare } & P . \text { diminuta } & \text { Strain 235 } \\ \text { GC content of DNA (moles \%) } & 65 \cdot 8 & 66 \cdot 3-67 \cdot 3 & 62 \cdot 2 \\ \text { Cystine requirement } & - & + & + \\ \text { Oxidase reaction } & \text { Weak } & \text { Strong } & \text { Weak } \\ \begin{array}{l}\text { Carotenoid production } \\ \text { Utilization of carbon sources } \\ \quad \text { D-glucose, D-galactose, maltose, } \\ \quad \text { c-llobiose }\end{array} & + & - & - \\ \begin{array}{l}\alpha \text {-Ketoglutarate } \\ \text { L-Histidine }\end{array} & + & - & - \\ \quad \begin{array}{l}\text { Pantothenate } \\ \text { Growth with 5\% ethanol in defined } \\ \text { medium }\end{array} & + & - & + \\ & - & + & + \\ & + & - & -\end{array}$

The diminuta group shares relatively few properties with the fluorescent pseudomonads, which must necessarily comprise the central cluster of the genus Pseudomonas, since they include its type species, $P$. aeruginosa (Stanier et al. 1966). It is therefore necessary to discuss briefly the taxonomic reasoning which has led us to include the diminuta group in the genus Pseudomonas. In some respects, the diminuta group resembles the polarly flagellated under-oxidizing acetic acid bacteria, now placed in a separate genus, Acetomonas (Leifson, 1954) or Gluconobacter (Asai \& Shoda, 1958). The features common to the two groups are the production of acids in complex media containing ethanol or aldose sugars, the production of acetone from isopropanol, and the multiple requirements for growth factors, which include pantothenate. However, under certain conditions the fluorescent pseudomonads also produce acids from ethanol (Stanier, 1947) and from glucose, and of the three groups in question only Acetomonas species are incapable of oxidizing acetate. In terms of over-all phenotype (flagellar morphology, nutritional spectra, relative acid tolerance, the chemical nature of the intracellular and extracellular pigments and of the intracellular reserve materials) the diminuta group appears to be at least as distinct from the fluorescent group as it is from the polarly flagellated acetic acid bacteria. One solution of this taxonomic problem would be to make extensive generic subdivisions among the aerobic pseudomonads, reserving the genus Pseudomonas for the fluorescent types. We are not opposed in principle to this solution, but, in our judgement, knowledge of the entire group is still insufficient to determine the bases on which the series of genera could best be created. As an interim taxonomic solution, we therefore favour the maintenance of a single 
genus Pseudomonas, broadly defined (Stanier et al. 1966). Both the diminuta group and the polarly flagellated acetic acid bacteria now classified in the genus Acetomonas can be satisfactorily accommodated in it as generic subgroups.

This work was supported by grants from the U.S. National Institutes of Health (AI-I 808) and from the National Science Foundation (GB-4I I2), as well as by traininggrant funds (USPH, AI-I20) awarded to the senior author. We thank Mrs Rebecca Contopoulou, Mrs Sharron Gentry and Miss Janet Bergendahl for their technical assistance and Dr Lautrop for his collection of cultures.

\section{REFERENCES}

Asal, T. \& Shoda, K. (1958). The taxonomy of Acetobacter and allied oxidative bacteria. J. gen appl. Microbiol. 4, 289.

Baumann, P., Doudoroff, M. \& Stanter, R. Y. (I968). A study of the Moraxella group. I. The genus Moraxella and the Neisseria catarrhalis group. J. Bact. 95, 53.

Busing, K. J., Doll, W. \& FreYtAG, K. (1953). Die Bakterienflora der medizinischen Blutegel. Arch. Mikrobiol. 19, 52.

CARR, F. H. \& PrICE, E. A. (1926). Colour reactions attributed to vitamin A. Biochem. J. 20, 497.

DAVIS, D. H. (1967). Studies on the Gram-negative hydrogen bacteria and related organisms. Ph.D. thesis, University of California, Berkeley.

Delafield, F. P., Doudoroff, M., Palleroni, N. J., Lusty, C. J. \& Contopoulou, R. (1965). Decomposition of poly- $\beta$-hydroxybutyrate by pseudomonads. J. Bact. 9o, 1455.

De LeY, J. \& Doudoroff, M. (1957). The metabolism of D-galactose in Pseudomonas saccharophila. J. biol. Chem. 227, 745.

ENTNER, N. \& DOUDOROFF, M. (1952). Glucose and gluconic acid oxidation by Pseudomonas saccharophila. J. biol. Chem. 196, 853 .

FeIGL, F. (1954). Spot Tests, 4th English ed. trans. by R. E. Oesper. Vol. I. Houston: Elsevier.

Galarneault, T. P. \& Leirson, E. (1964). Pseudomonas vesiculare (Busing et al.) comb.nov. Int. Bull. bact. Nonemcl. Taxon. 14, 165.

Hawk, P. B., Oser, B. L. \& Summerson, W. H. (1947). Practical Physiological Chemistry, I2th ed. Philadelphia: Blakiston.

HUGh, R. \& LeIFSON, E. (1953). The taxonomic significance of fermentative versus oxidative metabolism of carbohydrates by various Gram-negative bacteria. J. Bact. 66, 24.

LeIFSON, E. (195I). Staining, shape and arrangement of bacterial flagella. J. Bact. 62, 377.

Leifson, E. (1954). The flagellation and taxonomy of species of Acetobacter. Antonie van Leeuwenhoek 20, 102.

LeIrSON, E. \& HUGH, R. (1954). A new type of polar monotrichous flagellation. J. gen. Microbiol. ro, 68.

MacGee, J. \& Doudoroff, M. (1954). A new phosphorylated intermediate in glucose oxidation. J. biol. Chem. 196, 853 .

Mandel, M. (1966). Deoxyribonucleic acid base composition in the genus Pseudomonas. J. gen. Microbiol. 43, 273.

Redfearn, M. S., Palleroni, N. J. \& Stanier, R. Y. (I966). A comparative study of Pseudomonas pseudomallei and Bacillus mallei. J. gen. Microbiol. 43, 293.

Sands, D. C., Gleason, F. H. \& Hildebrand, D. C. (1967). Cytochromes of Pseudomonas syringae. J. Bact. 94, 1785 .

SLEPECKY, R. A. \& LAW, J. H. (1960). A rapid spectrophotometric assay of alpha, beta unsaturated acids and beta-hydroxy acids. Analyt. Chem. 32, 1697.

STANIER, R. Y. (1947). Acetic acid production from ethanol by fluorescent pseudomonads. J. Bact. 54, I9I.

Stanier, R. Y., Palleroni, N. J. \& Doudoroff, M. (I966). The aerobic pseudomonads: a taxonomic study. J. gen. Microbiol. 43, I59. 